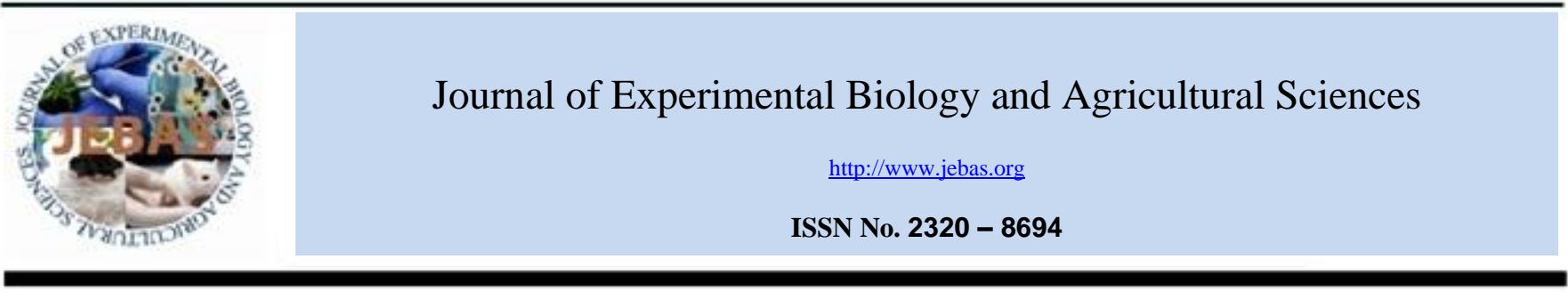

\title{
AN OVERVIEW OF OZONE THERAPY IN EQUINE- AN EMERGING HEALTHCARE SOLUTION
}

\section{Jyotsana Bhatt ${ }^{1, *}$, Abas Rashid Bhat ${ }^{1}$, Kuldeep Dhama $^{2}$ and Amarpal $^{3}$}

\author{
${ }^{1}$ Research Scholar, Division of Surgery, Indian Veterinary Research Institute, Izatnagar-243122 (UP), India \\ ${ }^{2}$ Principal Scientist, Division of Pathology, Indian Veterinary Research Institute, Izatnagar-243122 (UP), India \\ ${ }^{3}$ Head, Division of Surgery, Indian Veterinary Research Institute, Izatnagar-243122 (UP), India
}

Received - November 11, 2016; Revision - November 26, 2016; Accepted - December 10, 2016

Available Online - December 22, 2016

DOI: http://dx.doi.org/10.18006/2016.4(Spl-4-EHIDZ).S203.S210

KEYWORDS
Ozone therapy
Equine
Oxidative stress
Antioxidant
Hydrogen peroxide

\begin{abstract}
The significance of ozone therapy has been increasingly realised in recent times particularly in equine medicine. The beneficial effects of ozone therapy are basically engendered by the mild oxidative stress it creates upon interacting with the extra-cellular and intracellular components. However therapeutic benefits of treatment could be obtained only when it is used within the therapeutic window. Higher doses may be counterproductive and lower doses ineffective. It is now well proved that it up regulates the antioxidant system of the patient and may provide relief from many chronic degenerative diseases upon prolonged use. Ozone therapy has shown encouraging results in the treatment of wide spectrum of diseases and disorders in equines including bacterial and viral infections. Obvious benefits of ozone therapy have been reported in Equine infectious anemia, chlamydial abortions, lymphomas and equine ehrlichiosis. This article provides an insight into the mechanism of action involved in ozone therapy and reviews various conditions which could be treated with the use of ozone therapy in equines.
\end{abstract}

* Corresponding author

E-mail: bhattjyotsana24@gmail.com (Dr Jyotsana Bhatt)

Peer review under responsibility of Journal of Experimental Biology and Agricultural Sciences.

Production and Hosting by Horizon Publisher India [HPI] (http://www.horizonpublisherindia.in/).

All rights reserved.
All the article published by Journal of Experimental Biology and Agricultural Sciences is licensed under a Creative Commons Attribution-NonCommercial 4.0 International License Based on a work at www.jebas.org.

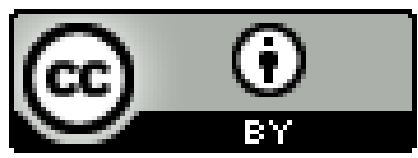




\section{Introduction}

Ozone molecule comprises of three atoms of oxygen arranged in a dihedral shape. This allotropic form of oxygen is less stable than oxygen due to the presence of mesomeric states (Elvis \& Ekta, 2011) and reacts with many other compounds like carbon and nitrous oxide. Ozone is 1.6 fold denser and 10fold more soluble in water than oxygen. It is the third most potent oxidant after fluorine and per-sulfate. Ozone is an unstable gas that cannot be stored and should be used at once because it has a half life of $40 \mathrm{~min}$ at $20^{\circ} \mathrm{C}$ and $140 \mathrm{~min}$ at $0^{\circ} \mathrm{C}$ (Cakir,2014).

In nature ozone is produced by the effect of electrical discharge on atmospheric oxygen during lightening or by ultraviolet radiation. It is a powerful oxidant and has many applications owing to its oxidant property. It is a highly reactive molecule which is able to inactivate microorganisms, boost the immune system and is also able to induce analgesic effect (Duricic et al., 2015). Ozone has many health benefits if used within the therapeutic window but may cause tissue damage if used above it. Ozone oxygenates every cell of the body and increases the stability of healthy cells. Medical ozone is a mixture of oxygen and ozone having less than $5 \%$ of ozone at maximum concentration and rest is pure oxygen (Bocci, 2006).

Unfortunately many clinicians and veterinary professionals are unaware of the therapeutic benefits and mechanism of action of ozone upon its interaction with biological fluids. As in most of the cases it is the dose which would decide the therapeutic or harmful effects of ozone. But it is now possible to perfectly tame the cytotoxicity of ozone by potent antioxidant system of the body. During last two decades scientists have made great efforts to understand the scientific mechanisms underlying the beneficial effects of ozone therapy at both basic research and clinical level. Ozone therapy has now been established as treatment of choice for many equine diseases like Equine infectious anaemia. Ozone therapy is also able to boost the antioxidant enzymes like superoxide dismutase, catalase, glutathione peroxidase etc. in the body (Mandhare et al., 2012).

\section{Ozone productions}

As in nature, ozone is produced by the action of lightening on oxygen, ozone generation can be achieved by passing oxygen across an electric arc having a potential difference of about 10,000 Volt in an ozone generator according to the following reaction-

$3 \mathrm{O}_{2}+68,400$ cal------ $2 \mathrm{O}_{3}$

An ozone generator must be made up of high quality ozone resistant material like teflon, glass, 316 stainless steel, silicone etc to resist oxidation (Mandhare et al., 2012). It should also be equipped with a photometer to measure the accurate concentration of ozone produced. There must also be a provision for temperature and humidity control as temperature and humidity also play important role in ozone production. A variety of ozone generators are available nowadays. However, three types of ozone generators are commonly used for production of medical ozone.

I. Corona discharge type- This type of ozone generators use corona discharge tube (high voltage electric field). They are cost effective and use ambient air as a source of oxygen. This type of ozone generators produce a concentration of $3-6 \%$ of ozone, however they also produce nitrous oxide as a by-product. A research showed the use of meshed-plate electrode in place of conventional plate has advantage of decreasing corona onset voltage and reduced decomposition of ozone thereby providing maximum ozone generation concentration and ozone generation efficiency (Park etal., 2006)

II. Ultraviolet lamp type- This type of ozone generators utilise a light source that generates a narrow-band ultraviolet light with a wavelength of approximately 185 $\mathrm{nm}$. They produce ozone with concentration of $0.5 \%$ or less but this type of ozone generators are cost effective than the corona discharge type generators as they consume less electricity. Added advantage of such type of generator is that it doesn't produces nitrous oxide (http://www.silvermedicine.org/ozone-therapygenerators.html).

III. Cold plasma type- In this type of generator oxygen gas is exposed to a plasma created by dielectric barrier discharge. These ozone generators breaks oxygen molecule in atoms of oxygen, which are very reactive and combines the available oxygen molecules to form a molecule of ozone. A maximal concentration of 5\% is produced in such generators (http://www.silvermedicine.org/ozone-therapygenerators.html).

Ozone molecule is very unstable so it must be prepared immediately before use. Within less than an hour after preparation only half of the mixture remained ozone while the rest half transformed into oxygen. Because of this characteristic it is impossible to store medical grade ozone for long period of time (Nogales et al., 2008).

\section{Mechanism of action of ozone}

Ozone on coming in contact with the blood acts on different targets and initiates a cascade of reactions thereby producing several beneficial effects. Unlike oxygen, ozone is very active gas and reacts as it comes in contact with blood or any other biological fluid. In order of preference, ozone reacts with polyunsaturated fatty acids (PUFA), protiens, antioxidants such as ascorbic acid and glutathione. 


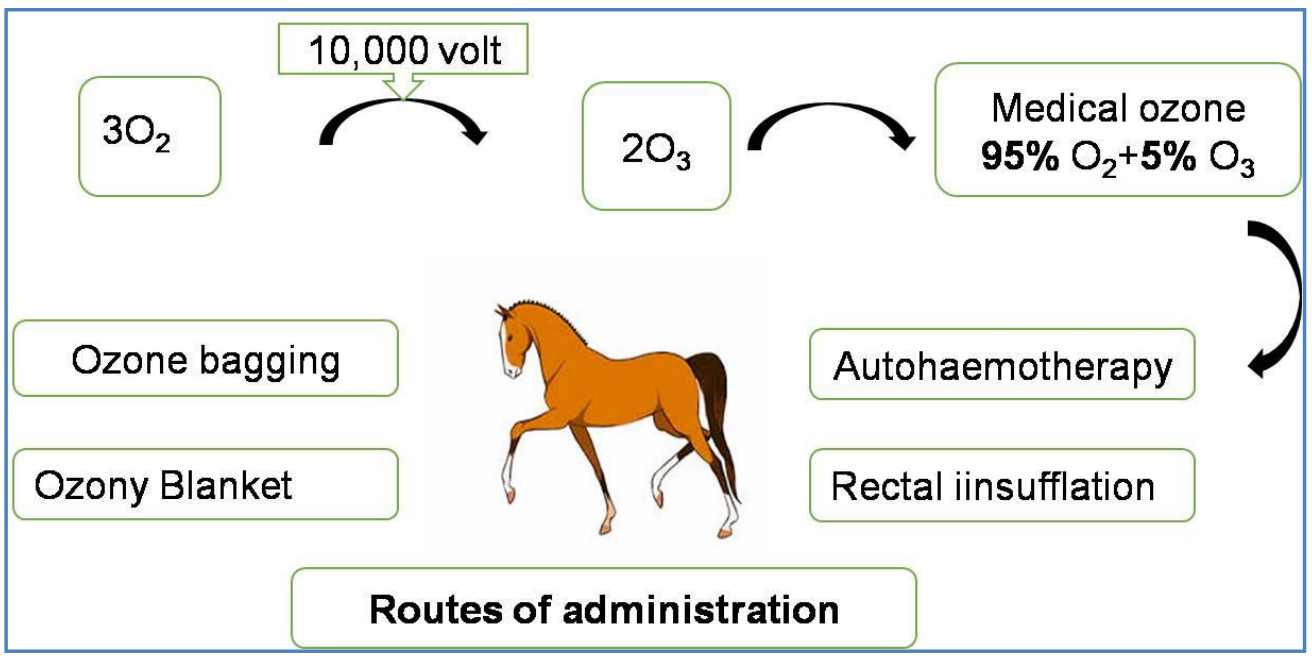

Figure 1 Schematic representation of ozone therapy procedure in horses.

On reaction with bio molecules it produces one molecule of reactive oxygen species (ROS) mainly hydrogen peroxide and two molecules of lipid oxidation products(LOP). The main reaction with bio molecules is depicted below:

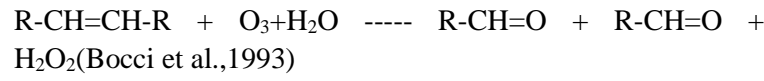

The by-products of the reaction tend to act in two different ways. ROS act immediately by reacting with erythrocytes which are available in the blood stream and disappear. This may be termed as early phase reaction, which is short lived. LOP, on the other hand, are distributed in the tissues and act on receptor molecules located at different locations in body, undergoing marked dilution within the circulatory system and thus their action may be termed as late phase reaction, which lasts longer.

ROS, particularly hydrogen peroxide, activates pentose phosphate pathway which is determined by the significant increase in the ATP formation (Bocci, 2005). LOPs produced in the reaction are mainly malonaldehyde and 4hydroxynonenal, which are very stable and toxic as well in vitro as compared to ROS. Fortunately, they undergo marked dilution in the circulation and gets metabolised upon blood distribution and redistribution in the body thus they reach at their target sites only in the submicromolar concentration thereby minimising their toxic effects.

Small concentration of LOPs extend their beneficial effect by up-regulation of the antioxidant enzymes like superoxide dismutase, glutathione peroxide etc (Iles \& Liu,2005). They also induce oxidative stress protein like Hemoxygenase-1(HO1) or Heat shock protein. HO-1 degrade the heme molecule into CO and bilirubin (Snyder \& Barañano, 2001). Bilirubin acts as a powerful antioxidant molecule whereas $\mathrm{CO}$ along with NO regulates the vasodilation by activating cGMP (Bocci,2006).

The mechanism of beneficial effects of ozone therapy may be summarised in the following ways-

I. It increases availability and delivery of oxygen, glucose and ATP within ischemic tissues.

II. It enhances implantation of bone marrow stem cells at the site of lesion, which can provide angiogenesis, neovascularization and tissue regeneration.

III. It activates a neurohumoral reaction responsible for improving quality of life.

IV. It induces up-regulation of the expression of antioxidant enzymes and heme-oxygenase $I$ and extends preconditioning benefits (Bocci,2006).

Ozone however could be toxic to the respiratory system, if inhaled, because respiratory tract lining has minimal amount of antioxidant coverage. In contrary to that blood has adequate amount of antioxidants to completely tame up the ozone toxicity, if used within the limits of therapeutic range. It is advisable that to enhance the safety of ozone therapy, prior to initiation of the therapy, antioxidant level of the patient body should be measured and should be strengthened by administration of antioxidants like vitamin $\mathrm{C}, \alpha$-tocopherol etc (Sagai \& Bocci,2011).

\section{Methods of administration of ozone}

\subsection{Auto-hemotherapy}

Autohemotherapy was first described by Wherli \& Steinbart in 1954. It may be major or minor autohemotherapy. 
In major autohemotherapy method around $250 \mathrm{ml}$ of blood is collected from the animal in heparin or $3.13 \%$ sodium citrate anticoagulant and the blood is ozonated outside the body of the animal for 5-10 minutes and then this ozonated blood is slowly infused back into the animal's body in over 15 minutes by intravenous routes. Ozonated autohemotherapy (O3-AHT) was used in the treatment of atherosclerotic ischemia of lower limb in human patients (Tylicki et al., 2004).While in minor autohemotherapy method, around $5 \mathrm{ml}$ of venous blood is collected from the patient without anticoagulant and ozonated outside the body for 1 minute. The ozonated blood is then injected intramuscularly (Borrelli \&Bocci, 2009). This minor autohaemotherapy approach had been used in treatment of chronic laminitis in a 10 years old mare (Coelho et al., 2015) and for mechanical lumbar pain in riding horses (Vigliani et al., 2005).

\subsection{Insufflation}

Insufflation of ozone is done in the body spaces like rectal, vaginal and ear canal. Rectal insufflation of ozone is most commonly practiced. Humidified ozonated gas can be introduced through the rectal opening to treat conditions like diarrhoea and inflammatory bowel disease caused by infections such as Rotavirus and Ehrlichia in horses. Rectal sufflation of medical ozone was also used in the treatment of patients with type 2 diabetes and diabetic feet (Martínez-Sánchez et al., 2005).

\subsection{Ozone bagging}

In this method an oxygen-ozone mixture is pumped into an ozone resistant bag which is then placed around the area to be treated. In this method superficial lesions can be treated as ozone is absorbed through the skin. The method has been applied for the treatment of cutaneous infections like chronic wounds and ulcers (Bocci, 2013).

\subsection{Ozonated oil}

In ozonated oil method the ozone is used with oil as a carrier of ozone. Ozone is bubbled in oil like olive, sesame or sunflower oil until it forms a gel like consistency, the gel can be used to treat several conditions like skin infections, insect stings, ulcers, vulvovaginitis and periodontitis (Shoukheba \& Ali, 2014 ).

\subsection{Ozony blanket}

In ozony blanket method an ozonated silicone blanket is placed around the horse body to ozonate the whole body of the animal. It could be used to treat several local and systemic conditions. This system proved to be very effective in treating various equine diseases (http://ozonyozone.weebly.com/ozonyblanket.html (accessed on 24/11/2016)

\section{Medical application of ozone therapy in equine}

Owing to its versatile biological action, ozone therapy is able to treat a wide variety of diseases and conditions. Equine medicine is a potential field for therapeutic exploitation of this modality as it has a capacity to reverse many serious illnesses. Initial studies suggested that ozone therapy could be very effective in treating many equine diseases by controlling infection, mitigating inflammation and improving anti-oxidant status.

Table 1 Some of the important studies showing beneficial outcome of ozone therapy in clinical cases of equine.

\begin{tabular}{|c|c|c|c|c|c|}
\hline S.no. & $\begin{array}{l}\text { Scientist / } \\
\text { Investigator }\end{array}$ & Disease condition & $\begin{array}{c}\text { Ozone } \\
\text { concentration }\end{array}$ & Site of administration & After effects \\
\hline 1 & $\begin{array}{l}\text { Coelho et al., } \\
2015\end{array}$ & Chronic laminitis & $19 \mathrm{mg} / \mathrm{L}$ & $\begin{array}{l}\mathrm{IM} \text {, at suprascapular } \\
\text { region, Near deep digital } \\
\text { flexor tendon }\end{array}$ & $\begin{array}{l}\text { Recovered to obel grade IV } \\
\text { to grade II of lameness }\end{array}$ \\
\hline 2 & $\begin{array}{l}\text { Vigliani et al., } \\
2005\end{array}$ & Mechanical lumbar pain & $30 \mu \mathrm{g} / \mathrm{ml}$ & $\begin{array}{l}\mathrm{IM} \text {, at interspinous and } \\
\text { paravertebral level }\end{array}$ & Effective analgesic effect \\
\hline 3 & $\begin{array}{l}\text { Shinozuka et } \\
\text { al., } 2008\end{array}$ & Mastitis & $0.8 \mathrm{mg} / \mathrm{l}$ & Into the affected quarter & $\begin{array}{l}\text { Signs of clinical mastitis } \\
\text { reversed }\end{array}$ \\
\hline 4 & $\begin{array}{l}\text { Akey \& } \\
\text { Walton, } 1985\end{array}$ & $\begin{array}{l}\text { Inactivation of } \\
\text { Venezuelan equine } \\
\text { encephalomyelitis virus }\end{array}$ & $0.025 \mathrm{mg} / \mathrm{L}$ & $\begin{array}{l}\text { Physical exposure for } 45 \\
\text { minutes }\end{array}$ & $\begin{array}{l}\text { reduction of } 99.99997 \% \text { of } \\
\text { the viral particles }\end{array}$ \\
\hline 5 & $\begin{array}{l}\text { Sechi et al., } \\
2001\end{array}$ & $\begin{array}{l}\text { Cutaneous wound } \\
\text { healing }\end{array}$ & $\begin{array}{c}1 \cdot 18- \\
9.5 \mathrm{mg} / \mathrm{ml}\end{array}$ & Topically as ozonised oil & $\begin{array}{l}\text { Better healing with increased } \\
\text { production of various growth } \\
\text { factors }\end{array}$ \\
\hline 6 & $\begin{array}{l}\text { Ozbay et al., } \\
2016\end{array}$ & Facial nerve paralysis & $\begin{array}{c}1.1 \mathrm{mg} / \mathrm{kg} \\
\text { body weight }\end{array}$ & Intraperitoneally & $\begin{array}{l}\text { Lower stimulation thresholds } \\
\text { in ozone treated group }\end{array}$ \\
\hline 7 & $\begin{array}{l}\text { Ouf } \\
\text { al.,2016 }\end{array}$ & Antifungal effect & $\begin{array}{l}4 \mu \mathrm{g} / \mathrm{ml} \\
0.5 \text { and } 0.25 \\
\mu \mathrm{g} / \mathrm{ml}\end{array}$ & $\begin{array}{l}\text { As ozone gas spray } \\
\text { As ozonised oil }\end{array}$ & $\begin{array}{l}\text { Better recovery with least } \\
\text { side effects }\end{array}$ \\
\hline
\end{tabular}


Several reports and clinical trials have appeared in the recent literature to prove the efficacy of ozone therapy as an adjunct therapy as well as a sole therapeutic agent. The following text describes various medical applications of ozone therapy in treating equine diseases.

\subsection{Chronic laminitis}

Chronic laminitis is a crippling disease of equine. It does not easily respond to standard medical therapy. Ozone therapy could be a solution for such cases. A case of chronic laminitis in a 10 year mare diagnosed with Obel grade IV chronic laminitis on right forelimb was successfully treated with ozone therapy (Coelho et al., 2015). On presentation the horse exhibited signs of laminitis like shifting lameness, high temperature, pain on palpation etc. On radiological examination distal phalanx of right limb was displaced by 30 degrees. Therapeutic regimen comprised of hoof trimming followed by intramuscular, peritendinous and intrarectal administration of medical ozone.

The injection of ozone was made at two suprascapular points located cranial and caudal to the scapula on both sides, two points were selected in scapular region, one point in the middle of the radial region and one near the deep digital flexor tendon. The selected points were clipped and aseptically prepared and a $10 \mathrm{ml}$ mixture of ozone-oxygen having a concentration of 19 mg ozone per $\mathrm{ml}$ was injected at each point. No NSAIDs or any other medication was used in the treatment regimen. Intrarectal insufflation of ozone was also performed. Ozone therapy was given twice a week for 10 weeks. Six months after therapy mare was able to walk properly along with normal relationship between the dorsal hoof wall and the distal phalanx on radiographic examination. Animal recovered up to the Obel grade II lameness with the help of this therapy (Coelho et al., 2015).

5.2 Mechanical lumbar pain and spinal muscle disorders in riding horse

Riding and thoroughbred horses which are commonly used for racing purpose frequently suffer from back pain. Its probable causes include bone or soft tissue injuries. In a study 30 horses suffering from back pain were treated with local infiltration of $15 \mathrm{ml}$ of oxygen-ozone mixture at the ozone concentration of $30 \mu \mathrm{g} / \mathrm{ml}$ into the affected muscle at interspinous and paravertebral level. This study proved efficacy of ozone therapy in pain management. Hence, ozone therapy could be considered as an alternative to NSAIDS treatment in cases of lumbar pain (Vigliani et al., 2005). It has been observed that during its administration, ozone produces an itchy sensation which is replaced by the analgesic effect as animal does not feel pain on palpation at the later stage. Supplementation with antioxidant in the form of vitamin $\mathrm{C}$ to maintain oxidantantioxidant balance could benefit the patient during ozone therapy (Ballardini, 2005).
5.3 Clinical mastitis in mares

Mastitis in mare is not quite common as in dairy cattle but can affect the health and productivity of mare adversely. Gram negative organisms accounted for mastitis in $42 \%$ of cases including Klebsiella and E.coli in $11.8 \%$ and $5.9 \%$ of cases, respectively (McCue \& Wilson, 1989). These gram negative microbes tend to develop endotoxic shock upon treatment with antibiotics. A study was conducted to compare the amount of endotoxin produced upon antibiotic therapy and ozone therapy.Results showed that in comparison to antibiotic therapy, ozone therapy $(0.8 \mathrm{mg} / \mathrm{L})$ resulted in less amount of endotoxin production (Shinozuka et al., 2008). It is observed that ozone therapy helps in reversing the local and systemic signs of acute clinical mastitis in animals. The therapeutic effects of ozone therapy could be attributable to increase in leukocytic function and increased respiratory burst. Ozone therapy can be preferred over antibiotic therapy in treating clinical mastitis as no milk withdrawal time is required with ozone therapy (Ogata \& Nagahata, 2000). However, it is not clear whether ozone functions by killing the pathogen or by improving the host defence mechanism.

\subsection{Enhancement of antioxidant capacity}

Oxidative stress can adversely affect the physical ability of performing horses. Ozonated autohemotherapy (OAHT) has shown to increase the antioxidant capacity of the blood. In a study 10 thoroughbred horses were examined for their biological antioxidant potential (BAP) after treating with ozone at the concentration of $20 \mu \mathrm{g} / \mathrm{kg}$ body weight .Same horses were used as control and for treatment. Control blood and serum samples were collected one month before the OAHT and for treatment group 1, 2, 3, 7 and 14 days later. Diacronreactive oxygen metabolites (d-ROMs) and biological antioxidant potential (BAP) was measured from serum samples to calculate oxidative stress index (OSI).BAP was increased significantly on day 3 and 7 in OAHT group as compared to control group (Tsuzuki et al., 2015).

\subsection{Inactivation of Venezuelan equine encephalomyelitis virus}

Humidified ozone gas is used as a sterilizing agent for medical instruments (Faddis, 1993). Ozone in liquid phase application at a concentration of $0.025 \mathrm{mg}$ per liter was able to inactivate arbovirus within $45 \mathrm{~min}$ of exposure. This study showed a reduction of $99.99997 \%$ of the viral particles as compared to the control levels. Hence ozone proved to be an effective candidate as a sterilizing agent in some applications for biological safety cabinets and other equipment used in vector studies with arboviruses (Akey \& Walton, 1985).

\subsection{Cutaneous wound healing}

Ozonated olive oil proved to be effective in healing of cutaneous wounds. 
In a study using guinea pigs as animal model the ozonated olive oil showed better wound healing in terms of lesser residual wound area, increased number of collagen fibres and fibroblast along with upregulation of various growth factors like PDGF, TGF- $\beta$ and VEGF in comparison to the group treated with simple olive oil and control group (Kim et al., 2009). Ozone used for wound treatment causes reduction in septic process and accelerates wound healing and also decreases the cost of antibiotic therapy (Białoszewski \& Kowalewski, 2003).A research showed increased angiogenesis, an enhanced vascular endothelial growth factors and cyclin D1 expression as a result of using ozonated sesame oil in cutaneous wound healing study model in SKH1 mice (Valacchi et al., 2011). In a study, effect of Oleozon (ozonised sunflower oil) was tested on Mycobacteria, staphylococci, streptococci, enterococci, Pseudomonas and Escherichia coli, which showed encouraging antimicrobial effects of oleozon on tested organisms (MIC range $1.18-9.5 \mathrm{mg} / \mathrm{ml}$ ) (Sechi et al., 2001).

\subsection{Neurological malfunctions (facial nerve paralysis)}

In a case record of 450 horses with signs of neurological disease, facial nerve paralysis was the most common type of cranial nerve injury (Tyler et al., 1993). Ozone therapy provides promising results in facial nerve regeneration. In a study comprised of fourteen Wistar albino rats, all animals underwent surgery in which the left facial nerve was exposed and crushed. Treatment with saline or ozone began on the day of the nerve crush. The ozone group received an ozone dose of $1.1 \mathrm{mg} / \mathrm{kg} / \mathrm{d}$ intraperitoneally (IP) for 30 days. Left facial nerve stimulation thresholds were measured before crush, immediately after crush, and after 30 days. Post-crushing, the ozone-treated group had lower stimulation thresholds than the saline group. In this study regeneration of the facial nerve was evaluated by assessing electrophysiological thresholds and by histopathological examination. This proves that ozonetherapy exerted beneficial effect on the regeneration of crushed facial nerves (Ozbay et al., 2016).

\subsection{Antifungal potential of ozone}

Fungal infection possesses a serious threat to animal health eventually leading to decreased productivity and work potential. Trichophyton equinum was recognized as the most common cause of equine ringworm in the United States, Canada, South America, and Europe (Georg et al., 1957). M. canis, T. Mentagrophytes varmentagrophytes, T. verrucosum, M. Praecox and M. Gypseum are also reported to be associated with equine ringworm (De Vroey et al., 1983). According to Ouf et al. (2016) Ozone therapy proved to be a better alternative in curing fungal infection and also prevents side effects of synthetic antifungal drugs due to their long term application. Fungal wall comprised of approximately $80 \%$ carbohydrates and $20 \%$ of proteins and glycoproteins with multiple disulfide bond making it possible site for oxidative inactivation by ozone. MIC for growth and spore germination for $M$. Gypseum and $M$. canis was $4 \mu \mathrm{g} / \mathrm{ml}$ in the case of ozone applied as gas and was 0.5 and $0.25 \mu \mathrm{g} / \mathrm{ml}$ in the case of ozonized oil. Application of ozone in the form of ozonized oil appears to be more efficacious than gaseous ozone.

\subsection{Other applications}

Several studies have been conducted to develop a non invasive technique of ozone therapy in which an ozone blanket is used to ozonate the whole body of the horse (http://ozonyozone.weebly.com/ozony-blanket.html accessed on 24/11/2016). This method has shown promising results in a wide range of ailments in horses. The method was developed by South African scientist Gail Pedra (http://ozonyozone.weebly.com/ozony-blanket.html accessed on 24/11/2016). These researchers treated a foal suffering from African Horse Sickness Virus in 2006 by ozonation of the whole body. This method is applied to treat illness by covering the animal inside an ozony blanket. Several conditions in which ozony blanket yields significant outcomes are sarcoma, African horse sickness, lyme disease, pro-active sport therapy etc. The ozony blankets have been used widely in South Africa and approximately 1000 horses have been successfully treated for disease control, prevention or enhancement of sports performance. This technique has various benefits as it is a completely portable device, even recumbent animal is able to receive treatment and multiple horses can be handled at one time.

\section{Conclusion}

The benefits of ozone therapy have been documented in numerous studies. It has been proved to be effective as an alternative treatment or as an adjunct treatment for many equine diseases like lameness, mastitis, bacterial and viral diseases, neurological and musculoskeletal disorders etc. Ozone acts to induce mild oxidative stress that can induce production of several anti-oxidant enzymes to benefit the patients and gradually being accepted as therapeutic modality in orthodox medicine. Medical grade ozone generators and photometers are essential for its optimum production and potential useful effects. There could be several methods of its administration, which should be standardised for maximum therapeutic benefits.

\section{Conflict of interest}

Authors would hereby like to declare that there is no conflict of interests that could possibly arise.

\section{References}

Akey DH, Walton TE (1985) Liquid-phase study of ozone inactivation of Venezuelan equine encephalomyelitis virus. Applied and Environmental Microbiology 50: 882-886.doi 0099-2240/85/100882-05\$02.00/0

Ballardini E (2005) Oxygen-Ozone Therapy for spinal muscle disorders in the horse. RivistaItaliana di Ossigeno- 
Białoszewski D, Kowalewski M (2003) Superficially, longer, intermittent ozone therapy in the treatment of the chronic, infected wounds. Ortopedia, Traumatologia, Rehabilitacja 5: 652-658.

Bocci VA (2006) Scientific and medical aspects of ozone therapy. State of the art. Archives of Medical Research37: 425435 .

Bocci V (2005) Ozone: A New Medical Drug. Springer Netherlands. 315 P. ISBN: 978-90-481-9233-5 (Print) 978-90481-9234-2 (Online)

Bocci V (2013) Oxygen-Ozone Therapy: A Critical Evaluation. Springer Science and Business Media : 338 .

Bocci V, Luzzi E, Corradeschi F, Paulesu L, Di Stefano A (1993) Studies on the biological effects of ozone: 3. An attempt to define conditions for optimal induction of cytokines. Lymphokine and Cytokine Research12: 121-126.

Borrelli E, Bocci V (2009) Basic biological and therapeutic effects of ozonetherapy in human medicine.UNESCOEncyclopedia for Advance Life Supports (EOLSS), Dec. 218-222.https://www.eolss.net/SampleChapters/C07/E6-192-15-00.pdf

Cakir R (2014) General Aspects of Ozone Therapy. In: Atrosh F (Ed.), Pharmacology and Nutritional Intervention in the Treatment of Disease,. INTECH Croatia DOI: 10.5772/57470

Coelho CS, Abreu-Bernadi W, Ginelli AM, Spagnol T, Gardel LS, Souza VRC (2015) Use of ozone therapy in chronic laminitis in a horse. Journal of Ozone Therapy 1: 30-35.

DeVroey C, Wuytack-Raes C, Fossoul F (1983) Isolation of saprophytic Microsporum praecox Rivalier from sites associated with horses. Sabouraudia: Journal of Medical and Veterinary Mycology 21: 255-257.

Đuričić D, Valpotić H, Samardžija M (2015) Prophylaxis and therapeutic potential of ozone in buiatrics: Current knowledge. Animal Reproduction Science 159: 1-7. DOI: 10.1016/j.anireprosci.2015.05.017

Elvis AM, Ekta J S (2011) Ozone therapy: A clinical review. Journal of Natural Science, Biology and Medicine2: 66.doi: 10.4103/0976-9668.82319

Faddis CG (1993) U.S. Patent No. 5,266,275. Washington, DC: U.S. Patent and Trademark Office.
Georg LK, Kaplan W, Camp LB (1957) Equine ringworm with special reference to Trichophytonequinum. American Journal of Veterinary Research18: 798-810.

Iles KE, Liu RM (2005) Mechanisms of glutamate cysteine ligase (GCL) induction by 4-hydroxynonenal. Free Radical Biology and Medicine38: 547-556.DOI: 10.1016/j.freeradbiomed.2004.11.012

Kim HS, Noh SU, Han YW, Kim KM, Kang H, Kim HO, Park YM (2009) Therapeutic effects of topical application of ozone on acute cutaneous wound healing. Journal of Korean Medical Science 24: 368-374.doi: 10.3346/jkms.2009.24.3.368.

Mandhare MN, Jagdale DM, Gaikwad PL, Gandhi PS, Kadam VJ (2012) Miracle of ozone therapy as an alternative medicine. International Journal of Pharmaceutical, Chemical and Biological Sciences 2 6371.http://www.ijpcbs.com/files/volume2-1-2012/06.pdf

Martínez-Sánchez G, Al-Dalain SM, Menéndez S, Re L, Giuliani A, Candelario-Jalil E, Álvarez H, FernándezMontequín JI, León OS (2005). Therapeutic efficacy of ozone in patients with diabetic foot. European journal of pharmacology $523: 151-61$.

McCue PM, Wilson WD (1989) Equine mastitis-a review of 28 cases. Equine Veterinary Journal 21: 351-353. DOI: 10.1111/j.2042-3306.1989.tb02687.x

Nogales CG, Ferrari PH, Kantorovich EO, Lage-Marques JL (2008) Ozone therapy in medicine and dentistry. The Journal of Contemporary Dental Practice 9: 75-84.

Ogata A, Nagahata H (2000) Intramammary application of ozone therapy to acute clinical mastitis in dairy cows. Journal of Veterinary Medical Science 62: 681-686.

Ouf SA, Moussa TA, Abd-Elmegeed AM, Eltahlawy SR (2016) Anti-fungal potential of ozone against some dermatophytes. Brazilian Journal of Microbiology 47:697-702. doi: 10.1016/j.bjm.2016.04.014.

Ozbay I, Ital I, Kucur C, Akc1lar R, Deger A, Aktas S, Oghan F (2016) Effects of ozone therapy on facial nerve regeneration. Brazilian Journal of Otorhinolaryngology 22: pii: S18088694(16)30045-3. doi: 10.1016/j.bjorl.2016.02.009.

Park SL, Moon JD, Lee SH, Shin SY (2006) Effective ozone generation utilizing a meshed-plate electrode in a dielectricbarrier discharge type ozone generator. Journal of Electrostatics 64: 275-282.

Sagai M, Bocci V (2011) Mechanisms of Action Involved in Ozone Therapy: Is healing induced via a mild oxidative stress? Medical gas research 1: 29.doi: 10.1186/2045-9912-1-29 
Sechi LA, Lezcano I, Nunez N, Espim M, Duprè I, Pinna A, Zanetti S (2001) Antibacterial activity of ozonized sunflower oil (Oleozon). Journal of Applied Microbiology90: 279-284.

Shinozuka Y, Uematsu K, Takagi M, Taura Y (2008) Comparison of the amounts of endotoxin released from Escherichia coli after exposure to antibiotics and ozone: an in vitro evaluation. Journal of Veterinary Medical Science70: 419-422.doi: http://doi.org/10.1292/jvms.70.419

Shoukheba MYM, Ali SA (2014) The effects of subgingival application of ozonated olive oil gel in patient with localized aggressive periodontitis. A clinical and bacteriological study. Tanta Dental Journal 11: 6373.http://dx.doi.org/10.1016/j.tdj.2014.04.001

Snyder SH, Barañano DE (2001) Heme oxygenase: a font of multiple messengers. Neuropsychopharmacology25: 294298.doi:10.1016/S0893-133X(01)00275-5

Tsuzuki N, Endo Y, Kikkawa L, Korosue K, Kaneko Y, KitauchiA,Torisu S (2015) Effects of ozonatedautohemotherapy on the antioxidant capacity of Thoroughbred horses. The Journal of Veterinary Medical Science77: 1647-1650.doi: 10.1292/jvms.15-0225
Tyler CM, Davis RE, Begg AP, Hutchins DR, Hodgson DR (1993) A survey of neurological diseases in horses. Australian Veterinary Journal70: 445-449.

Tylicki L, Biedunkiewicz B, Nieweglowski T, Chamienia A, Slizien AD , Luty J, Rutkowski B (2004) Ozonatedautohemotherapy in patients on maintenance hemodialysis: influence on lipid profile and endothelium. Artificial organs 28: 234-237.DOI: 10.1111/j.15251594.2003.47211.x

Valacchi G, Lim Y, Belmonte G, Miracco C, Zanardi I, Bocci V, Travagli V (2011) Ozonated sesame oil enhances cutaneous wound healing in SKH1 mice. Wound Repair and Regeneration19: $\quad$ 107-115.doi: $\quad 10.1111 / \mathrm{j} .1524-$ 475X.2010.00649.x.

Vigliani A, BonipertiE, Scudo E (2005) Paravertebral O2-O3 Treatment in Mechanical Lumbar Pain in Riding Horses. RivistaItaliana di Ossigeno-Ozonoterapia4: 6469.https://o3vets.com/wpcontent/uploads/2013/11/Paravertebral-Treatment-Equine.pdf accessed on $24 / 11 / 2016$

Wehrli F, Steinbart H (1954) Erfahrungenmit der haematogenenOxydations - Therapie (HOT). Ars Medici 10: 44-51. 